\title{
CYST-THECA RELATIONSHIPS OF GONYAULACALES AND PERIDINIALES (DINOPHYCEAE) FROM BAHÍA CONCEPCIÓN, GULF OF CALIFORNIA
}

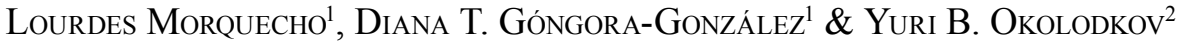 \\ ${ }^{1}$ Centro de Investigaciones Biológicas del Noroeste, Mar Bermejo 195, \\ colonia Playa Palo de Santa Rita, 23090 La Paz, Baja California Sur, México. \\ lamorquecho@cibnor.mx \\ ${ }^{2}$ Universidad Veracruzana, Centro de Ecología y Pesquerías, \\ calle Hidalgo núm. 617, colonia Río Jamapa, 94290 \\ Boca del Río, Veracruz, México.yurikolodkov@yahoo.com
}

\begin{abstract}
Based on samples obtained in 2000-2002 from a 1-cm layer of surface sediment at two sites in Bahía Concepción in the Gulf of California, cyst-theca relationships were defined from cyst germination assays for Gonyaulax spinifera (= Spiniferites mirabilis), Protoceratium globosum, Preperidinium meunieri (= Dubridinium caperatum), Protoperidinium denticulatum (= Brigantedinium irregulare), and Protoperidinium cf. thorianum. All the taxa are illustrated with photomicrographs and descriptions of the resting and vegetative stages are given, including synonymy, size variation, distribution in Mexico, and global distribution, when known. As a result of cyst germination assays, the previously unknown cyst-theca relationship of $P$. globosum was described. We also confirmed the presence of the vegetative stage of $P$. denticulatum in the Gulf of California and heterospory in G. spinifera from Bahía Concepción. Cultures of G. spinifera and P. globosum were successfully established.
\end{abstract}

Keywords: cyst-theca relationships, dinoflagellates, Gonyaulacales, Gulf of California, Mexican Pacific, Peridiniales.

\section{RESUMEN}

Mediante ensayos de germinación se logró definir la relación quiste-teca de Gonyaulax spinifera (= Spiniferites mirabilis), Protoceratium globosum, Preperidinium 
meunieri (= Dubridinium caperatum), Protoperidinium denticulatum (= Brigantedinium irregulare) y Protoperidinium cf. thorianum. Los quistes se aislaron a partir del primer centímetro de sedimento superficial de muestras colectadas durante el periodo 20002002 en Bahía Concepción, Golfo de California. Los taxa identificados se ilustran con microfotografias, se describe la morfología de los estadios quístico y vegetativo, y también se incluye información sobre sinonimias, variación en talla y su distribución en México y en el mundo. Los ensayos de germinación permitieron describir por primera vez la relación quiste-teca de $P$. globosum, confirmar la presencia del estadio vegetativo de $P$. denticulatum en el Golfo de California y de la heterosporia en G. spinifera. También se establecieron con éxito cepas de G. spinifera y P. globosum.

Palabras clave: dinoflagelados, Golfo de California, Gonyaulacales, Pacífico mexicano, Peridiniales, relación quiste-teca.

\section{INTRODUCTION}

The life cycle of many dinoflagellates includes a motile flagellate stage and a non-motile cyst stage. Dinoflagellate cysts can survive at low temperature, under anoxic and dark conditions, and represent a key stage in the survival of a species and its spatial dispersion over extended time periods (Hallegraeff \& Bolch, 1992).

In recent years, morphological studies of dinoflagellate cysts by germination experiments have been increasingly regarded as important in the classification of modern dinoflagellates, elucidation of the role of cysts in their life cycle and survival strategy, detection of harmful species seed beds, and determination of geographic distribution and patterns of succession (Wall \& Dale, 1966; Bolch et al., 1991; Kokinos \& Anderson, 1995; Sonneman \& Hill, 1997; Kremp, 2000; Ellegaard et al., 2001; Ellegaard et al., 2002; Matsuoka et al., 2006). Morphology of resting cysts is regarded as an important character in species diagnosis, which at present is principally based on the morphology of the vegetative stage (Montresor et al., 1993). However, much confusion still exists regarding the taxonomic relationships of many resting cysts and their corresponding motile stages (Sonneman \& Hill, 1997). Additionally, many of these species have two names because the cyst and motile stages were described and named independent of one another by palynologists and phycologists, respectively (Ellegaard et al., 2001). We used the classification of living and fossil dinoflagellates proposed by Fensome et al. (1993); in most cases we cited the biological name, but both set of names, including authors, are sumarized in Table 1. 
Table 1. Cited names and authors of Gonyaulacales and Peridiniales, based on their motile and cyst stages.

\begin{tabular}{|c|c|c|}
\hline Order & Biological taxon & Cyst-based taxon \\
\hline \multirow[t]{11}{*}{ Gonyaulacales } & Gonyaulax digitalis (Pouchet) Kof. & Bitectatodinium tepikiense Wilson \\
\hline & $\begin{array}{l}\text { Gonyaulax membranacea } \\
\text { (Rossignol) Ellegaard et al. }\end{array}$ & $\begin{array}{l}\text { Spiniferites membranaceus } \\
\text { (M. Rossignol) Sarjeant }\end{array}$ \\
\hline & $\begin{array}{l}\text { Gonyaulax spinifera (Clap. et } \\
\text { Lachm.) Diesing }\end{array}$ & $\begin{array}{l}\text { Nematosphaeropsis labyrinthus } \\
\text { (Ostenfeld) Reid }\end{array}$ \\
\hline & & $\begin{array}{l}\text { Spiniferites mirabilis (M. } \\
\text { Rossignol) Sarjeant }\end{array}$ \\
\hline & & Tectatodinium pellitum (Wall) \\
\hline & & Head \\
\hline & $\begin{array}{l}\text { Lingulodinium polyedra (F. Stein) } \\
\text { J. D. Dodge }\end{array}$ & \\
\hline & $\begin{array}{l}\text { Protoceratium globosum Kof. et J. } \\
\text { R. Michener }\end{array}$ & \\
\hline & $\begin{array}{l}\text { Protoceratium reticulatum (Clap. et } \\
\text { J. Lachm.) Bütschli }\end{array}$ & $\begin{array}{l}\text { Operculodinium centrocarpum } \\
\text { (Deflandre et Cookson) Wall }\end{array}$ \\
\hline & (= Gonyaulax grindleyi Reinecke) & $\begin{array}{l}\text { Operculodinium israelianum } \\
\text { (Rossingnol) Wall }\end{array}$ \\
\hline & & Operculodinium psilatum Wall \\
\hline \multirow[t]{6}{*}{ Peridiniales } & $\begin{array}{l}\text { Preperidinium meunieri (Pavill.) } \\
\text { Elbr. }\end{array}$ & Dubridinium caperatum Reid \\
\hline & $\begin{array}{l}\text { Protoperidinium avellana } \\
\text { (Meunier) Balech }\end{array}$ & $\begin{array}{l}\text { Brigantedinium cariacoense } \\
\text { (Wall) Reid }\end{array}$ \\
\hline & $\begin{array}{l}\text { Protoperidinium conicoides } \\
\text { (Paulsen) Balech }\end{array}$ & Brigantedinium simplex Wall \\
\hline & $\begin{array}{l}\text { Protoperidinium denticulatum } \\
\text { (Gran et Braarud) Balech }\end{array}$ & $\begin{array}{l}\text { Brigantedinium irregulare } \\
\text { Matsuoka ex Head }\end{array}$ \\
\hline & $\begin{array}{l}\text { Protoperidinium cf. thorianum } \\
\text { (Paulsen) Balech }\end{array}$ & \\
\hline & Scrippsiella trochoidea (F. Stein) & \\
\hline
\end{tabular}

There are 1555 marine dinoflagellates species living today (Gómez, 2005) and at least 180 of them produce organic-walled resting cysts (Head, 1996). The main 
morphological characteristics used to identify dinoflagellate cysts are the general morphology of the body and ornamentation, structure and color of the wall, and archeopyle type (Matsuoka \& Fukuyo, 2000). In most cases the archeopyle is essential to discriminate between major taxa of dinoflagellates. However, living cyst archeopyles are hard to see under light microscopy before germination, so it is difficut to use this character to identify morphotypes, particularly from the Gonyaulacales and Peridiniales because of their complex and very similar morphology. For example, in the Gonyaulacales, heterospory led taxonomists to propose groups or species complexes (Dale, 1983; Lewis et al., 1999). Whether the motile stages have been underclassified or cysts overclassified, is under discussion (Taylor \& Gaines, 1989; Ellegaard et al., 2003). The cysts of Protoperidinium Bergh and the Diplopsalioideae are dominant heterotrophic groups in extant dinoflagellate benthic assemblages. However, most of their cysts are spherical and have a simple external morphology. Therefore, they are very difficult to identify, except for the archeopyle shape and position, and no information on tabulation can be inferred (Matsuoka et al., 2006).

Studies of dinoflagellate cysts in Mexico are scanty and carried out mainly in the northwestern coastal zone along the Pacific. In Bahia de Todos Santos on the Pacific coast of the State of Baja California, 18 species of organic-walled dinoflagellate cysts were identified, with gonyaulacalean and peridinialean cysts being the predominant morphotypes (Peña-Manjarrez et al., 2005). According to MartínezHernández and Hernández-Campos (1991), the organic-walled peridinialean cysts, represented mainly by Protoperidinium conicoides and P. avellana, were common groups in the Gulf of California. In general, the gonyaulacalean cysts were scarce within the Gulf and only Gonyaulax spinifera was frequent in the Guaymas basin (middle region of the Gulf of California), particularly in phosphorus-rich sediments. In Bahía Concepción (Fig.1), the calcareous Peridiniales and Gonyaulacales cysts were the most abundant morphotypes, mainly represented by Lingulodinium polyedra and Scrippsiella trochoidea (Morquecho \& Lechuga-Devéze, 2003).

The thecal morphology of the vegetative stage of 17 Protoperidinium species from the southwestern coast of Mexico has been recently studied in detail by Okolodkov (2005). However, some previously reported Peridiniales species had been misidentified and the diversity of the group is underestimated (Okolodkov, 2002; Okolodkov et al., 2003; Okolodkov \& Gárate-Lizárraga, 2006). The taxonomy of the genus Gonyaulax Diesing and Gonyaulacales in general has not been studied in detail in Mexico and some species had also been misidentified (Okolodkov \& Gárate-Lizárraga, 2006). 
Studies of dinoflagellate benthic cysts in any given area can reveal species not previously found in the water column because the vegetative stage is rare, shortlived, or difficult to identify. The objective of this survey was to establish cyst-theca relationships in selected Gonyaulacales and Peridinales species in Bahía Concepción in the Gulf of California.

\section{MATERIAL AND METHODS}

Sediment samples were collected every 15 days from January 2000 to December 2001, and from April to June 2002 with a gravity corer equipped with plastic tubes (20 cm long, $1.3 \mathrm{~cm}$ diameter) at two sites in Bahía Concepción (Fig. 1). The

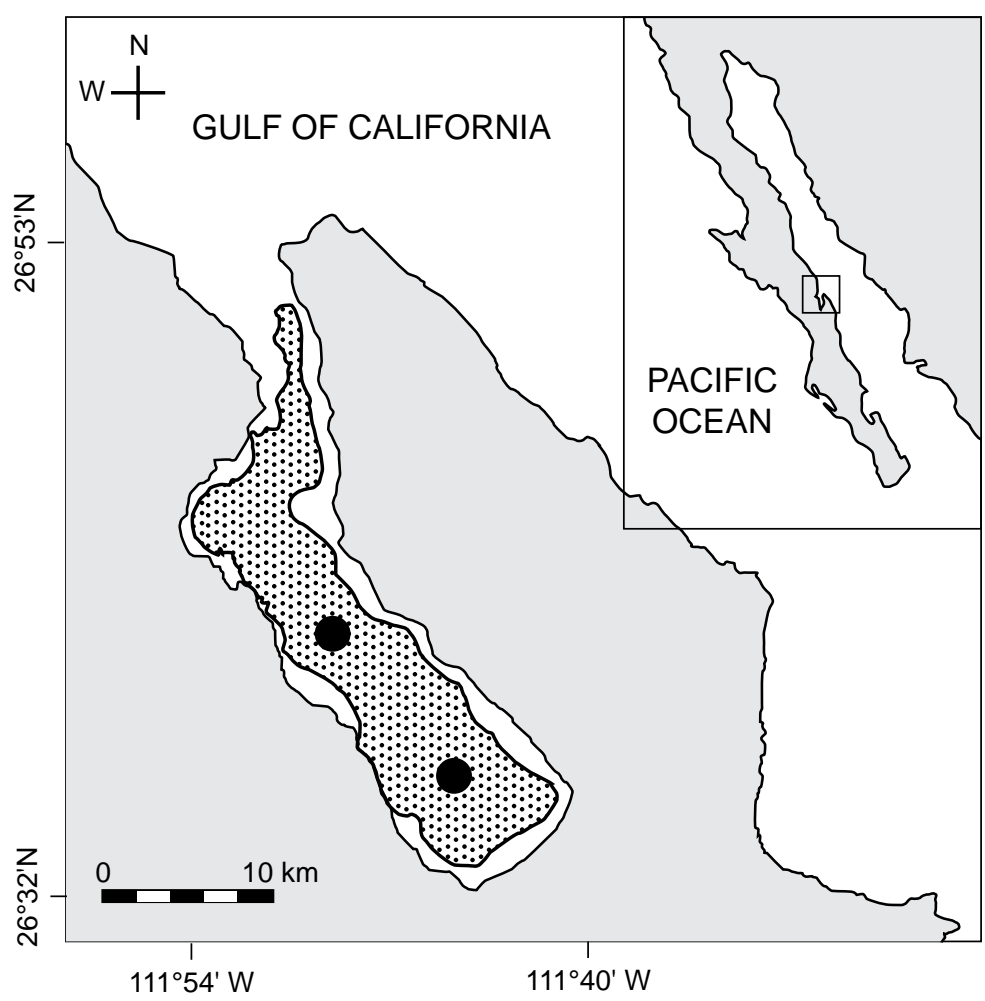

Fig. 1. Sampling sites (black circles) in Bahía Concepción, Gulf of California during 20002002. The stippled area indicates green mud (Meldahl et al., 1997). 
samples were wrapped in aluminium foil and stored in the dark at $20 \pm 3{ }^{\circ} \mathrm{C}$ until examination. The water column was 27-30 $\mathrm{m}$ deep and the sea floor was composed of mud (Meldahl et al., 1997) that experienced seasonal eutrophication (LechugaDevéze et al., 2001; Morquecho \& Lechuga-Devéze, 2004). Abundance and cyst assemblages of recent sediments in Bahía Concepción were compiled by Morquecho \& Lechuga-Devéze (2003). Seasonal variations in the phytoplankton community, particularly in meroplanktonic dinoflagellates and physico-chemical characteristics of the water column during the sediment collection period were described by Morquecho and Lechuga-Devéze (2004).

To define cyst-theca relationships, the uppermost centimeter of each sample was processed by the method for cleaning and concentrating cysts described by Matsuoka et al. (1989) and Matsuoka \& Fukuyo (2000). The sediment was gently sonicated for $5 \mathrm{~min}$. with an ultrasonic cleaner (Branson Ultrasonics, Danbury, CT, USA), filtered through a $100-\mu \mathrm{m}$ mesh sieve to remove large sediment particles, and then filtered through a $20-\mu \mathrm{m}$ mesh sieve and washed with filtered seawater. Samples were stored in 15-ml plastic tubes. Aliquots of 1-1.5 ml were studied with an inverted Carl Zeiss Axiovert 100 microscope (Oberkochen, Germany) equipped with $40 \times / 0.60$ and $63 \times / 0.90$ phase contrast objectives. The entire Utermöhl plate chamber bottom was scanned to look for and isolate living cysts.

Single live cysts were isolated with a micropipette, rinsed with sterile seawater, and placed in 24-well culture plates previously filled with $2 \mathrm{ml} \mathrm{GSe}$ (Doblin et al., 1999) or modified $\mathrm{f} / 2$ (Bravo \& Anderson, 1994) culture media without silicates. After sealing the plates with plastic tape to prevent evaporation, the plates were incubated at $20 \pm$ $3{ }^{\circ} \mathrm{C}$ and $25 \pm 1{ }^{\circ} \mathrm{C}$ on a $12: 12 \mathrm{~h}$ dark:light cycle with light intensity of $40.7 \mu \mathrm{E} \mathrm{m}^{-2} \mathrm{~s}^{-1}$.

Cysts were examined regularly under the inverted microscope to detect germination. Experiments in which cysts did not germinate within 15 days were discarded. After germination, vegetative cells were re-isolated and fixed with acidic Lugol's solution. For plate pattern identification, the cells were placed on a slide and treated with a diluted sodium hypochlorite solution and theca stains, trypan blue (Lebour, 1925) and iodine (Imamura \& Fukuyo, 1987).

Observations of empty cysts and vegetative cells were first made under brightfield and phase-contrast illumination with the inverted microscope and then with a compound microscope equipped with a $2 x$ U-ECA magnification changer, using $10 \times / 0.25$ and $40 \times / 0.65$ phase contrast objectives (Olympus BX41, Tokyo, Japan). Photographic records of live and empty cysts and vegetative cells were made with a Media Cybernetics CoolSnap-Pro digital camera (Silver Spring, MD, USA) and Image-Pro Plus version 4.0 (Silver Spring, MD, USA) imaging software. 
The names of the Mexican states were abbreviated: Baja California Sur (B.C.S.), Baja California (B.C.), Sonora (Son.), Sinaloa (Sin.), Nayarit (Nay.), Jalisco (Jal.), Colima (Col.), Michoacán (Mich.), Guerrero (Gro.), Oaxaca (Oax.), Chiapas (Chis.), and Veracruz (Ver.). The names of the thecal plates were abbreviated according to the Kofoid tabulation system as follows: first apical plate ( $\left(1^{\prime}\right)$, first intercalary plate (1a), second intercalary plate (2a), first precingular plate (1"), and second precingular plate (2"). Abbreviations of authors of scientific names were used according to Brummitt and Powell (1992), unless they were not listed in the book.

\section{RESULTS}

From cyst germination assays, we observed cyst-theca relationships and germination patterns for five dinoflagellate species. It was not possible to establish cultures from germination assays of the organic-walled Peridinialean cysts; only a few vegetative cells were obtained. Three strains of Gonyaulacales were successfully established and have been maintained since 2002.

\section{A. Gonyaulacales cyst-theca relationships}

Gonyaulax spinifera (Clap. et J. Lachm.) Diesing, 1866 (Figs. 2-12)

Bas.: Peridinium spiniferum Clap. et J. Lachm., 1858.

Cyst stage: Tectatodinium pellitum are proximate cysts with a spherical body (30.9-49 $\mu \mathrm{m}, \mathrm{n}=3$ ), and lack spines (Fig. 2). The cyst wall is weakly pigmented and consists of a thin pedium and a thicker spongy luxuria. The external surface of the luxuria has a roughened texture. The archeopyle is precingular and formed by the loss of the 3" plate (Figs. 3 and 4). The archeopyle margin is irregular, but with adcingular angles well defined.

Taxonomic note: Germinated cysts match the size and morphological characteristics of the holotype of T. pellitum Wall, emended by Head in 1994, as well as with the specimens germinated by Wall \& Dale (1968). The slight apical protuberance included by Head (1994) in the emended diagnosis was observed in only some specimens (not shown on the photographic plate).

Motile stage: Cells germinated from T. pellitum cysts are conical, large (37$63 \mu \mathrm{m}$ by $30-50 \mu \mathrm{m}, \mathrm{n}=5$ ), slightly longer than broad with an apical horn and two antapical spines (Figs. 7-9). The sides of the epitheca were straight to convex, form- 


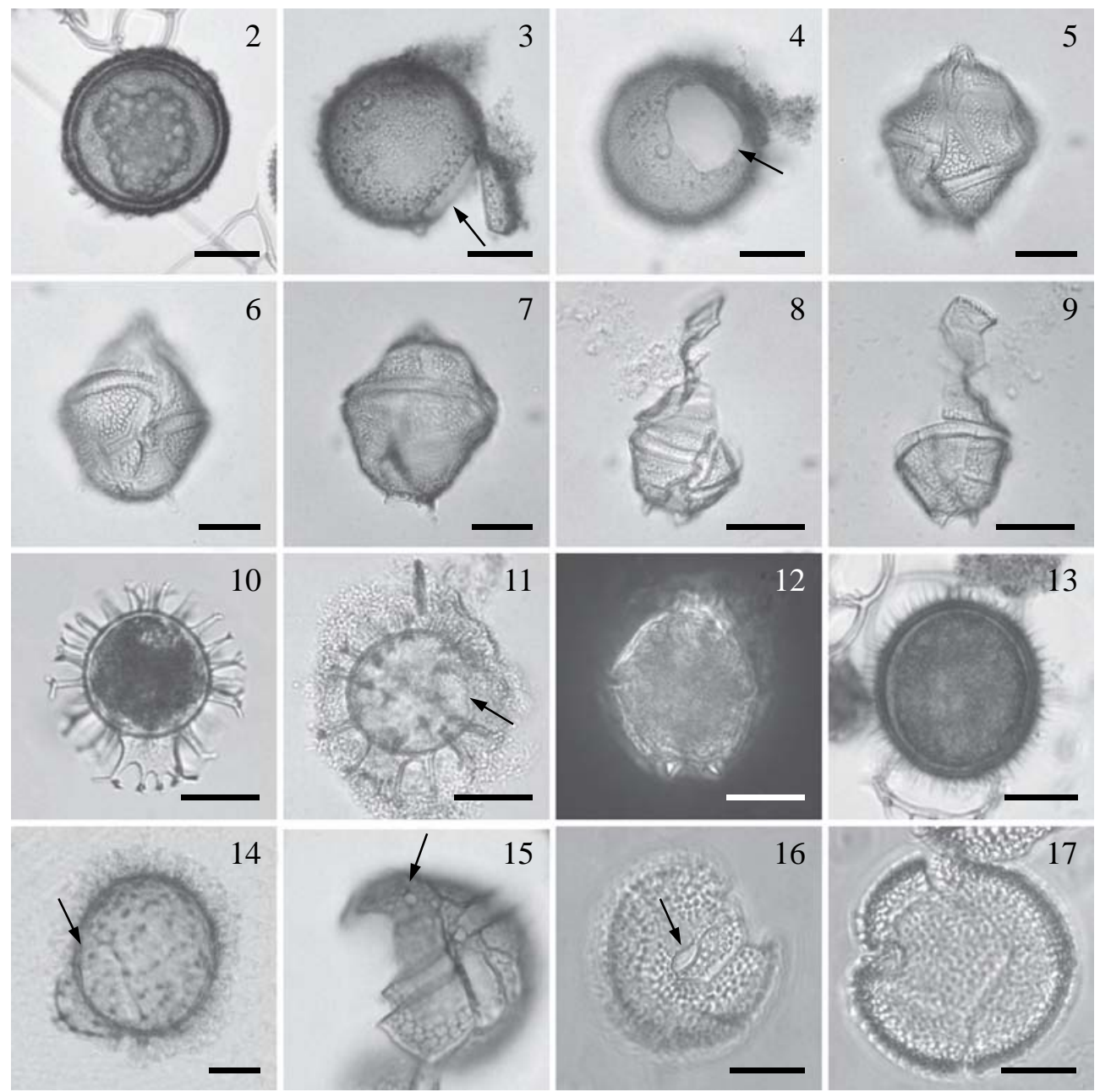

Figs. 2-17. Cyst-theca relationships of Gonyaulacales isolated from Holocene sediments in Bahía Concepción in the Gulf of California. (2-9) Gonyaulax spinifera germinated from Tectatodinium pellitum cyst: (2) living cyst, (3, 4) empty cyst with archeopyle (arrow), (5) vegetative cell in ventral view, (6) vegetative cell showing cingular displacement, (7) vegetative cell in dorsal view, $(8,9)$ empty theca showing antapical spines. (10-12) Gonyaulax spinifera germinated from Spiniferites mirabilis cyst: (10) living cyst, (11) empty cyst with archeopyle (arrow), (12) vegetative cell showing antapical spines. (13-17) Protoceratium globosum: (13) living cyst, (14) empty cyst with archeopyle (arrow), (15) vegetative cell in dorsal view showing the ventral pore (arrow), (16) epitheca showing the Po plate, (17) hypotheca. Scale bars $=20 \mu \mathrm{m}$. 
ing broad shoulders at one-third the distance from the apex. The hypotheca have straight sides and rounded antapex. The girdle is deeply excavated, descendent with overhanging ends, displaced by 2 to 3 times its width. The plates are thick and heavily ornamented. It was impossible to culture this species; growth was unstable and irregular and very few vegetative cells survived for a short time.

Taxonomic note: Wall \& Dale (1968, pl.1 Figs. 11 and 12) also established the correlation between cysts of T. pellitum with G. spinifera and cell size and morphological characteristics, particularly the cingulum displacement and presence of two antapical spines, that match the specimens described in this study.

Cyst stage: Spiniferites mirabilis is a chorate cyst with an ovoid to spherical central body ( $35 \mu \mathrm{m}$ in diameter, $\mathrm{n}=1)$ and a number of vallate, hystricate, and antheriform processes (Figs. 10 and 11). The girdle width was $5.2 \mu \mathrm{m}$ and the height of the processes 7.9 to $15.7 \mu \mathrm{m}$. The antapical region has a prominent flange that extends distally to form several proceses (Fig. 10). The quadrangular archeopyle is located on the dorsal epicyst and reflects the loss of the 3 ' pre-cingular paraplate (Fig. 11). The cyst wall is transparent and the cytoplasm has a red stigma that is clearly visible.

Taxonomic note: The morphology of our cyst is very similar to the specimens described by Wall and Dale (1968, Pl. 1 Fig. 10) and Reid (1974, Pl. 4, Figs. 32, 33, and 34), except the size. The germinated cyst from Bahía Concepción is smaller compared with the measurements of $26 \times 40$ to $42 \times 59 \mu \mathrm{m}$ reported by Reid (1974).

Motile stage: The cell germinated from $S$. mirabilis is rhomboidal $(44.5 \mu \mathrm{m} \times$ $38 \mu \mathrm{m}, \mathrm{n}=1$ ) has a short apical horn and a variable number of small antapical spines, two of them prominent (Fig. 12). The girdle is displaced by two girdle widths with an overlap of at least one third of the width of the cell. The thecal plates are heavily ornamented with a reticulated pattern. Culture of this species in GSe medium was successful.

Taxonomic note: Preliminary observations of the theca with light microscopy led to recognition of this dinoflagellate as G. spinifera. A scaning electron microscopy analysis will be conducted to corroborate this. Gonyaulax membranacea produce cysts very similar to G. spinifera (Reid, 1974), therefore a careful observation of the theca, particularly ornamentation and reticulation pattern is needed (Ellegaard et al., 2003).

Distribution in Mexico (based on the motile stage): West coast of Baja California Peninsula, B.C.S., Son., Sin., and Nay. bordering the Gulf of California and Jal., Col., Oax., and Chis. (Okolodkov \& Gárate-Lizárraga, 2006) bordering the southwestern coast of Mexico on the Pacific.

Global distribution (based on the motile stage): The G. spinifera complex has a panthalassic distribution, having been reported in almost all Arctic marginal seas, 
North Atlantic, the Mediterranean, tropical and temperate waters of the Pacific, Atlantic, and Indian oceans, the Drake Passage, and to the NE of the Ross Sea, Antarctica. Cysts may contribute up to $100 \%$ of the dinoflagellate cyst assemblages in surface sediments in northern and southern temperate waters and tropical waters (Marret \& Zonneveld, 2003).

Protoceratium globosum Kof. et J. R. Michener, 1911 (Figs. 13-17)

Cyst stage: Proximochorate type with a spherical body $(30-35 \mu \mathrm{m}$ long, $\mathrm{n}=3)$. The cyst wall is transparent and covered with numerous short $(3.3-4.7 \mu \mathrm{m})$, transparent, hollow, and wide-based conical processes ending as sharp points (Figs. 13 and 14). The saphopylic archeopyle results from the loss of the 3 " plate. The archeopyle angles are slightly rounded.

Taxonomic note: The cyst of $P$. globosum is very different from Operculodinium centrocarpum. The main differences are in shape and length of the processes, as well as the archeopyle shape. In O. centrocarpum, the processes are longer and can be slender to stout, with simple capitate or minutely hooked tips, and the archeopyle has a subtriangular to trapezoidal aperture (Wall \& Dale, 1968; Reid, 1974; Sonneman \& Hill, 1997). Wall \& Dale (1968) and Rochon et al. (1999) reported that Protoceratium reticulatum produces more than one morphologically distinct kinds of resting spores that correlates with the fossil species $O$. centrocapum, $O$. israelianum, and $O$. psilatum. The latter is different from our specimen, despite possessing processes similar in length $(2-3 \mu \mathrm{m})$, which are fewer and have a girdle zone and ventral sulcal scar that is prominently developed.

Motile stage: The cells are polygonal and rounded (38.5-46.2 $\mu \mathrm{m}$ in diameter, $\mathrm{n}=18$ ). The theca is thick and deeply aerolate (Figs. 15-17). The po plate is oval, has a curved cavity, and is surrounded by three apical plates. The girdle displacement about one girdle width. In ventral view, the epitheca shows a large ventral pore on the 1' plate (Fig. 15). Two strains were successfully established and maintained with GSe nutrient medium.

Taxonomic note: Although Kofoid and Michener (1911) did not illustrate their new species, our specimens are a good match with their description. P. globosum differs from $P$. denticulatum in having a more rounded or globular shape (epitheca and hipoteca is more or less equal in size), and the cingulum list are less developed. Okolodkov and Gárate-Lizárraga (2006) also observed these differences and that the intercalary plate is wider in samples collected in several localities along the Mexican Pacific. We identified P. reticulatum in Hargraves \& Maranda (2002: Fig. 20) and in 


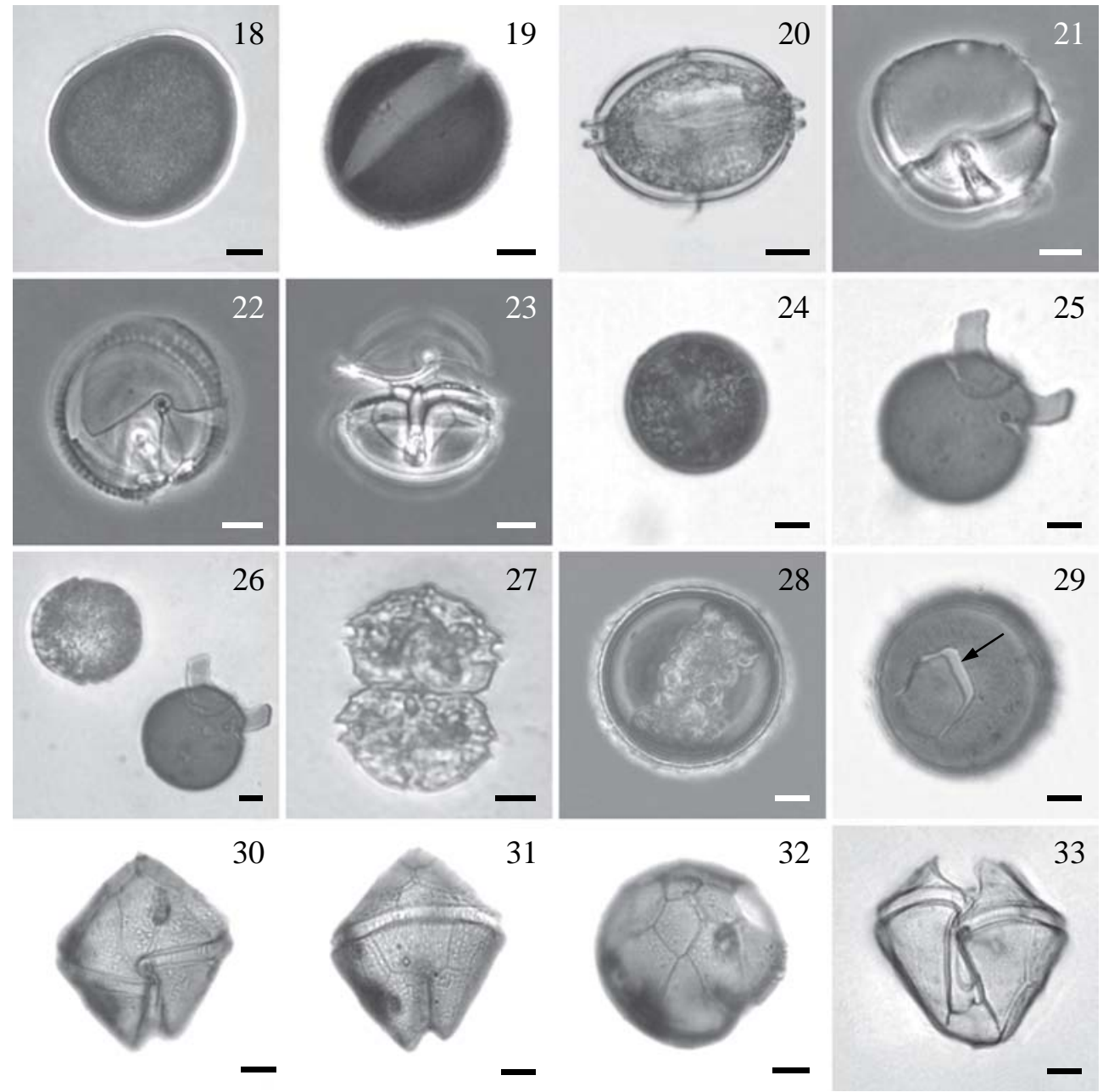

Figs. 18-33. Cyst-theca relationships of Peridiniales isolated from Holocene sediments in Bahía Concepción in the Gulf of California. (18-23) Preperidinium meunieri: (18) living cyst, (19) empty cyst with archeopyle, (20) vegetative cell in ventral view, (21, 22) epitheca in apical view, (23) sulcal plates. (24-27) Protoperidinium denticulatum: (24) living cyst, (25) empty cyst with archeopyle, (26) a newly excysted vegetative cell $(45.7 \times 42.3 \mu \mathrm{m})$ with flagella completely developed and swam slowly near the empty cyst, (27) a pair of vegetative cells in dorsal view. (28-33) Protoperidinium cf. thorianum: (28) living cyst, (29) empty cyst with archeopyle (arrow), (30, 31) vegetative cell in ventral and dorsal views, (32) epitheca, (33) sulcal plates. Scale bars $=10 \mu \mathrm{m}$. 
Vargas-Montero and Freer (2002: Fig. 4A) and Gonyaulax grindleyi in Faust et al. (2005: Figs. 2-5) as P. globosum.

Distribution in Mexico (based on the motile stage): Okolodkov \& GárateLizárraga (2006) reported P. globosum from Jal., Col., Mich, Gro., and Oax.

Global distribution: This is unknown. The species has been reported and documented with illustrations from the northeastern coast of the United States, Costa Rica, and the Mexican coast on the Pacific (Hargraves \& Maranda, 2002; Vargas-Montero \& Freer, 2002; Faust et al., 2005; Okolodkov \& Gárate-Lizárraga, 2006).

\section{B. Peridiniales cyst-theca relationships}

Preperidinium meunieri (Pavill.) Elbr., 1993 (Figs. 18-23)

Bas.: Peridinium meunieri Pavill., 1912; non Peridinium meunieri N. Peters, 1930. Tax. syn.: Diplopsalis lenticula (Bergh) f. minor Paulsen, 1907; Peridinium lenticulatum L. Mangin, 1911; Peridinium paulseni L. Mangin, 1911; Diplopeltopsis minor (Paulsen) Pavill., 1913; Diplopsalis minor (Paulsen) Paulsen, 1930; Glenodinium lenticula (Bergh) Pouchet f. minor (Paulsen) J. Schill., 1937; Zygabikodinium lenticulatum Loebl. et A. R. Loebl., 1970; Dubridinium caperatum P. C. Reid, 1977 (cyst stage); Diplopsalopsis minor (Paulsen) T. H. Abé, 1981.

Cyst stage: The Dubridinium caperatum cyst is lenticular in ventral view, dark brown in color (Figs. 18 and 19), parasulcus and paracingulum, and apical pore complex are easily observed (not shown in the photographic plate). The cyst wall consists of a loose, thin, wrinkled outer layer and a thicker, inner layer with a finely granulated surface. The archeopyle is theropylic; the operculum comprises all of the epicystal paraplates and always remains attached (Fig. 19). Length 35-48 $\mu \mathrm{m}$, width 41-54 $\mu \mathrm{m}(\mathrm{n}=5)$.

Taxonomic note: The general characteristics and dimensions of the cysts and archeopyle match descriptions given by Wall \& Dale (1968) and Sonneman \& Hill (1997).

Motile stage: The cell is lenticular in ventral view and circular in apical view. The pitheca and hypotheca are similar in size and shape (Fig. 20). The 1' plate is ortho, with the anterior triangle longer than the posterior one. The 1a plate is small and rhomboid, while the 2a plate is large, occupying almost half of the epitheca (Fig. 21). The pore complex consists of an elliptical pore plate and a small rectangular canal plate. The cingulum is circular, planozone, with well developed lists and ribs. Some 
cells show unusual sutures (Figs. 21 and 23). Plate formula: Po, x, 3', 2a, 7", 3c, 5s, $5^{\prime \prime \prime \prime}, 1^{\prime \prime \prime \prime}$ Length 26-36 $\mu \mathrm{m}$, width 43-54 $\mu \mathrm{m}$, depth 42-50 $\mu \mathrm{m}(\mathrm{n}=3)$.

Taxonomic note: Infraspecific variations in tabulation pattern of $P$. meunieri are likely related to accidental events during ontogenesis and were observed (not shown).

Distribution in Mexico (based on the motile stage): Gulf of California (B.C.S.), Jal. (Morquecho \& Lechuga-Devéze, 2003, 2004; Okolodkov \& Gárate-Lizárraga, 2006).

Global distribution: A panthalassic species reported from the Arctic Ocean, Chukchi, Kara, Barents, and White Seas, northoreast Atlantic, Baltic, North, Black, and Mediterranean Seas, tropical areas of the Pacific, Atlantic, and Indian Oceans, Australian and Argentinian coastal waters, the Bellinghausen, Weddell, and Ross Seas (Okolodkov, 1998; unpubl. observ.).

Protoperidinium denticulatum (Gran et Braarud) Balech, 1974 (Figs. 24-27) Bas.: Peridinium denticulatum Gran et Braarud, 1935.

Cyst stage: Brigantedinium irregulare cyst is spherical, smooth, and dark brown in color (Fig. 24). The archeopyle is theropylic, hexagonal, laterally elongated, and formed by the loss of the 1a and 2a paraplates (Fig. 25). Diameter 40-45 $\mu \mathrm{m}(\mathrm{n}=2)$. Germination occurred $62 \mathrm{~h}$ after isolation and inoculation (Fig. 26).

Motile stage: Asexual cell division resulted in unequal vegetative cells of $P$. denticulatum (Fig. 26). It has a pentagonal shape in ventral view, that is short and wide. The epitheca is conical, with a wide base and almost straight sides and a distinctive slit grove at the apex. The 1' plate is ortho; there are only two intercalary plates. The girdle cavozone, with descending one girdle-width displacement. The sulcus is deep. Cells frequently occur in pairs (Fig. 27). Length $23.8 \mu \mathrm{m}$, width 39.4 $\mu \mathrm{m}(\mathrm{n}=2)$.

Taxonomic note: The morphological characteristics of the cyst of $P$. denticulatum from Bahía Concepción closely match the descriptions given by Gran \& Braarud (1935), Wall \& Dale (1968), and Sonneman \& Hill (1997). The first authors also germinated cysts and obtained paired cells morphologically very similar to those described in this study. However, the cells reported by Wall \& Dale (1968) are longer (50-60 $\mu \mathrm{m})$.

Distribution in Mexico: Cysts: Bahía Concepción, Gulf of California (Morquecho \& Lechuga-Devéze, 2003). Motile stage: Cabo Corrientes, Jal. (Okolodkov \& Gárate-Lizárraga, 2006), Ver., Gulf of Mexico (Okolodkov, 2008). 
Global distribution (based on the motile stage and cysts): Neritic, broad ranging species in the North Atlantic, Laptev and Chukchi Seas in the Arctic, Sea of Japan, Chinese coastal waters, southern Gulf of Mexico, the Mexican subtropical and tropical Pacific and the SW Atlantic (Balech, 1988; Nehring, 1994, 1995, 1997a,b; McQuoid et al., 2002; Wang et al., 2004a,b).

Protoperidinium cf. thorianum (Paulsen) Balech, 1974 (Figs. 28-33)

Cyst stage: Spherical, not ornamented, dark brown color (Fig. 28). The archeopyle theropylic, hexagonal; operculum remains attached (Fig. 29). Diameter 58 $\mu \mathrm{m}(\mathrm{n}=1)$.

Taxonomic note: Cyst of $P$. thorianum described by Sonneman and Hill (1997) is morphologicaly similar to specimen in this study. Similarly, the operculum remains attached to the cyst and the diameter of the specimen from Bahía Concepción approximates the size mentioned by these authors $(45-55 \mu \mathrm{m})$.

Motile stage: Pentagonal in ventral view, it has conical epitheca and hypotheca with two short conical horns. The 1' plate is ortho; its right suture is longer than the left one and is curved near the cingulum (Figs. 30 and 31). Only two intercalary plates are present, hexagonal and similar in size. The pore plate is long, elliptic, extending into the $3^{\prime}$ plate and the canal plate is as long as the pore plate (Fig. 32). Girdle cavozone, descending, with a two girdle width displacement and slightly overhanging ends. The sulcus is deep (Fig. 33). Length $57 \mu \mathrm{m}$, width $54 \mu \mathrm{m}(\mathrm{n}=1)$.

Taxonomic note: The vegetative cell of $P$. cf. thorianum that we examined is similar to the original description of $P$. thorianum in its tabulation pattern and the right suture of the 1' plate. However, our specimen lacks a papillated surface and has a deeper sulcus. This variation suggests that our specimen represents a variety of the species; confirmation with cyst germination assays should be done. The vegetative stage of $P$. thorianum has been reported in the Gulf of California only by Licea-Durán et al. (1995) and Hernández-Becerril $(1988,1991)$. It can be confused with P. avellana, which does not have a rugose surface and has a narrower sulcus and a median cingulum (Steidinger \& Tangen 1997). Additionally, the archeopyle in the P. avellana cyst has a characteristic hexagonal form, which is an important taxonomic feature.

Distribution in Mexico (based on the motile stage): Protoperidinium thorianum occurs in the Gulf of California (B.C.S., Sin.), and Jal. and Mich. along the Pacific (Okolodkov \& Gárate-Lizárraga, 2006).

Global distribution (based on the motile stage): P. thorianum is a neritic cosmopolitan species found from Tierra de Fuego to Baffin Bay in the Atlantic, from 
southeast Australia to the Bering Strait in the Pacific, from Greenland across to Alaska in the Eurasian arctic, and in the northern Indian Ocean (Dogde, 1982; Sonneman \& Hill, 1997; Steidinger \& Tangen, 1997).

\section{DISCUSSION}

Gonyaulacales and Peridiniales are among the most important microphytoplankton components globally (Gómez, 2005). The taxonomy of these orders is particularly difficult, but studies of cyst-theca relationships have greatly helped to define species composition in several places around the world (Lewis, 1990; Zonneveld \& Dale 1994; Montresor et al., 1997; Kremp, 2000; Ellegaard et al., 2002; Matsuoka et al., 2006). The photographic record of germination patterns presented in this survey is of particular importance. It documents, for the first time, Protoceratium globosum as a cyst-producing species. Additionally, confirming the Protoperidinium denticulatum cyst-theca relationship allowed us to demonstrate cyst viability and presence of the vegetative stage in the Gulf of California.

Morquecho \& Lechuga-Devéze (2003) reported empty cysts of $P$. denticulatum in Bahía Concepción; therefore, the global distribution of this species also includes subtropical areas. The vegetative stage of $P$. denticulatum is extremely rare along the Mexican coast of the Pacific; formerly found in phytoplankton samples collected at Cabo Corrientes (Okolodkov \& Gárate-Lizárraga, 2006). This species appears to have spread to new areas, where it exists for only a short time in the motile stage before encysting rapidly and spending most of the time in the cyst stage.

The germination assays let us demonstrate heterospory in the resting stage of Gonyaulax spinifera from Bahía Concepción because more than one cyst was attributed to this species. However, it is clear that an accurate taxonomic revision involving scanning electron microscopy, molecular biology, and life cycle studies are required (see Matsuoka et al., 2006). Because of so-called heterospory, the resting stage of G. spinifera has received several paleontological names, including Spiniferites mirabilis, Tectatodinium pellitum, Nematosphaeropsis labyrinthus, Bitectatodinium tepikiense. Even more cysts with other paleontological names are related with the G. spinifera complex as a biological affinity (Head, 1996; Rochon et al., 1999). However, the names cannot be synonymous because the taxa produce morphologically different types of cysts that most likely correspond to different species of the G. spinifera complex (Martin J. Head, pers. comm., February 2007). Ellegaard et al. (2003) demonstrated that motile stages obtained from germinating several Spinife- 
rites cysts and $B$. tepikiense, which were previously attributed to the $G$. spinifera complex, belong to distinct species of the genus Gonyaulax, which in the motile stage, show small morphological differences, but relatively high genetic divergence.

For cyst germination assays, it is important to consider the culture media for heterotrophic dinoflagellates; some species require organic compounds that could be supplied with the addition of specific chemical substances (urea or glycerol) or the use of live food, such as other algae (diatoms and cynobacteria). In this survey, in all the cases where organic-walled Peridiniales cysts germinated, successive division of vegetative cells failed and only survived for a few days. Additionaly, it was impossible to examine the theca of G. spinifera germinated from T. pellitum, $P$. denticulatum, and $P$. cf. thorianum in detail because establishing the culture failed. Similar inconveniencies were also reported by Ellegaard et al. (2003), in cultures of Gonyaulax species that showed only short periods of survival. Additionally, the empty cysts of P. globosum were lost when we tried to isolate them from the multidish plate. Cultures that are successfully established would permit experiments to induce cyst production for accurately describing their morphology and study the vegetative growth and influence of temperature and salinity on cyst morphology.

Spherical brownish and Gonyaulacales cysts in sediments of Bahía Concepción are a component of the cyst assemblage and contribute to diversity of dinoflagellate species in the bay and the Gulf (Martínez-Hernández \& Hernández-Campos, 1991; Morquecho \& Lechuga-Devéze, 2003). In this survey and the initial research of Morquecho \& Lechuga-Devéze (2003), only ten particular cyst-theca relationships were described. However, it is highly probable that other unreported species with similar morphotypes exist.

In summary, this survey presents qualitative features of cysts within the orders Gonyaulacales and Peridiniales found in an important bay within the Gulf of California. Establishing the cyst-theca relationships and the illustrations of the germination patterns provide useful taxonomic information on dinoflagellate species from the Gulf of California. It is clear that a complementary study involving culturing of these species under controlled conditions, molecular techniques, scanning electron microscopy, and life cycle description is needed.

\section{ACKNOWLEDGMENTS}

We appreciate the field and laboratory work of Iban Murrillo, Francisco Hernández, and Felipe Zapata. Malte Elbrächter at Deutsches Zentrum für Marine Biodiver- 
sitätsforschung, Forschungsinstitut Senkenberg, Germany and Martin J. Head from Brock University, St. Catharines, Ontario, Canada provided important suggestions to improve the manuscript, as did the anonymous reviewers. Marcia M. Gowing at the University of California at Santa Cruz kindly improved the text. Boris Okolodkov assisted in preparing a map of sampling sites. This survey was supported by Consejo Nacional de Ciencia y Tecnología of Mexico (CONACYT grant R33598-B).

\section{LITERATURE CITED}

Balech, E. 1988. Los dinoflagelados del Atlántico sudoccidental. Publicaciones Especiales del Instituto Español de Oceanografia. No. 1. Madrid. 310 pp.

Bolch, C. J., S. I. Blackburn, J. A. Cannon \& G. M. Hallegraeff. 1991. The resting cyst of the red-tide dinoflagellate Alexandrium minutum (Dinophyceae). Phycologia 30(2): 215-219.

Bravo, I. \& D. M. Anderson. 1994. The effects of temperature, growth medium and darkness on excystment and growth of the toxic dinoflagellate Gymnodinium catenatum from northwest Spain. J. Plankton Res. 16(5): 513-525.

Brummitt, R. K. \& C. E. Powell (eds.). 1992. Authors of plant names. A list of authors of scientific names of plants with recommended standard forms of their names, including abbreviations. Royal Bot. Gardens. Kew. United Kingdom. 732 pp.

Dale, B. 1983. Dinoflagellate resting cysts: benthic plankton. In: Fryxell, G. A. (ed.). Survival strategies of the algae. Cambridge Univ. Press. Cambridge. pp. 69-136.

Doblin, M. A., S. I. Blackburn \& G. M. Hallegraeff. 1999. Comparative study of selenium requirements of three phytoplankton species: Gymnodinium catenatum, Alexandrium minutum (Dinophyta) and Chaetoceros cf. tenuissimus (Bacillariophyta). J. Plankton Res. 21(6): 1153-1169.

Dodge, J. D. 1982. Marine dinoflagellates of the British Isles. HM Stat. Office. London. 303 pp.

Ellegaard, M., B. Dale \& A. Amorim. 2001. The acritarchous cyst of the athecate dinoflagellate Warnowia cf. rosea (Dinophyceae). Phycologia 40(6): 542-546.

Ellegaard, M., J. Lewis \& I. Harding. 2002. Cyst-theca relationship, life cycle, and effect of temperature and salinity on the cyst morphology of Gonyaulax baltica sp. nov. (Dinophyceae) from the Baltic Sea area J. Phycol. 38(4): 775-789.

Ellegaard, M., N. Daugbjerg, A. Rochon, J. Lewis \& I. Harding. 2003. Morphological and LSU rDNA sequence variation within the Gonyaulax spinifera-Spiniferites group (Dinophyceae) and proposal of G. elongata comb. nov. and G. membranacea comb. nov. Phycologia 42(2): 151-164.

Faust, M. A., R. W. Litaker, M. W. Vandersea, S. R. Kibler \& P. A. Tester. 2005. Dinoflagellate diversity and abundance in two Belizean coral-reef mangrove lagoons: a test of Margalef's Mandala. Atoll Res. Bull. 534: 105-131. 
Fensome, R. A., F. J. R. Taylor, G. Norris, W. A. S. Sarjeant, D. I. Wharton \& G. L. Williams. 1993. A classification of living and fossil dinoflagellates. Micropaleontology Special Papers. Sheridan Press. Hanover, PA. 351 pp.

Gómez, F. 2005. A list of free-living dinoflagellate species in the world's oceans. Acta Bot. Croat. 64(1): 129-212.

Gran, H. H. \& T. Braarud. 1935. A quantitative study of the phytoplankton in the Bay of Fundy and the Gulf of Maine (including observations on hydrography, chemistry and tubidity). J. Biol. Board. Can. 1(5): 279-467.

Hallegraeff, G. M. \& C. J. Bolch. 1992. Transport of diatom and dinoflagellate resting spores in ships' ballast water: implications for plankton biogeography and aquaculture. J. Plankton Res. 14(8): 1067-1084.

Hargraves, P. E. \& L. Maranda. 2002. Potentially toxic or harmful microalgae from the northeast coast. Northeast. Nat. 9(1): 81-120.

Head, M. 1994. Morphology and paleoenvironmental significance of the Cenozoic dinoflagellate genera Tectatodinium and Habibacysta. Micropaleontology 40(4): 289321.

Head, M. J. 1996. Modern dinoflagellate cysts and their biological affinities. In: Jansonius, J. \& D. C. McGregor (eds.). Palynology: principles and applications. American Association of Stratigraphic Palynologists Foundation. Dallas, Texas. Vol. 3. pp. 1197-1248.

Hernández-Becerril, D. U. 1988. Especies de fitoplancton tropical del Pacífico Mexicano. II. Dinoflagelados y Cianobacterias. Rev. Lat-amer. Microbiol. 30(2): 187-196.

Hernández-Becerril, D. U. 1991. Protoperidinium (Dinophyceae) species in the Gulf of California and off the coasts of Baja California. An. Inst. Cienc. del Mar y Limnol. 18(1): 77-88.

Imamura, K. \& Y. Fukuyo. 1987. Method for observation of theca plates of armored dinoflagellates. A guide for studies of red tide organisms. Japan Fisheries Resources Conservation Association Shuwa. Tokyo. pp. 54-73.

Kofoid, C. A. \& J. R. Michener. 1911. Reports of the scientific results of the expedition to the eastern tropical Pacific in charge of Alexandre Agassiz, 22. New genera and species of dinoflagellates. Bull. Mus. Comp. Zool. Harv. Coll. 54: 267-302.

Kokinos, J. P. \& D. M. Anderson. 1995. Morphological development of resting cysts in cultures of the marine dinoflagellate Lingulodinium polyedrum (= L. machaerophorum). Palynology 19: 143-166.

Kremp, A. 2000. Morphology and germination pattern of the resting cysts of Peridiniella catenata (Dinophyceae) from the Baltic Sea. Phycologia 39(3): 183-186.

Lebour, M. V. 1925. The dinoflagellates of northern seas. Marine Biological Association of the United Kingdom. Plymouth, United Kingdom. 250 pp.

Lechuga-Devéze, C. H., A. Reyes-Salinas \& M. L. Morquecho-Escamilla. 2001. Anoxia in a coastal bay: a case of study of a seasonal event. Rev. Biol. Trop. 49(2): 525-534.

Lewis, J, A. Rochon \& I. Harding. 1999. Preliminary observations of cyst-theca relationships in Spiniferites ramosus and Spiniferites membranaceus (Dinophyceae). Grana Suppl. 3: $1-12$.

Lewis, J. 1990. The cyst-theca relationship of Oblea rotunda (Diplopsalidaceae, Dinophyceae). Br. Phycol. J. 25(1): 339-351. 
Licea-Durán, S., J. L. Moreno-Ruiz, H. Santoyo-Reyes \& G. Figueroa. 1995. Dinoflagelados del Golfo de California. Universidad Autónoma de Baja California Sur, Secretaría de Educación Pública, Fondo para la Modernización de la Educación Superior, Programa Interdisciplinario e Insterinstitucional del Mar de Cortés. México, D.F. 165 pp.

Marret, F. \& K. Zonneveld. 2003. Atlas of modern organic-walled dinoflagellate cyst distribution. Rev. Palaeobot. Palynol. 125(1-2): 1-200.

Martínez-Hernández, E. \& H. Hernández-Campos. 1991. Distribución de quistes de dinoflagelados y acritarcas en sedimentos holocénicos del Golfo de California. Paleontol. Mex. 57: 1-133.

Matsuoka, K., Y. Fukuyo \& D. M. Anderson. 1989. Methods for modern dinoflagellate cysts studies. In: Okachi, T., D. M. Anderson \& T. Nemoto (eds.). Red tides: biology, environmental science and toxicology. Elsevier. New York. pp. 461-480.

Matsuoka, K. \& Y. Fukuyo. 2000. Guía técnica para el estudio de quistes de dinoflagelados actuales. WESTPAC-HAB/ WESTPAC /IOC. Tokyo. 30 pp.

Matsuoka, K., H. Kawami, R. Fujii \& M. Iwataki. 2006. Further examination of the cysttheca relationship of Protoperidinium thulesense (Peridiniales, Dinophyceae) and the phylogenetic significance of round brown cysts. Phycologia 45(6): 632-641.

McQuoid, M., A. Godhe \& K. Nordberg. 2002. Viability of phytoplankton resting stages in the sediments of a coastal Swedish fjord. Eur. J. Phycol. 37(2): 191-201.

Meldahl, K. H., O. González-Yajimovich, C. D. Empedocles, C. S. Gustafson, M. MotoliniaHidalgo \& T. W. Reardon. 1997. Holocene sediments and molluscan faunas of Bahía Concepción: a modern analog to Neocene rift basins of the Gulf of California. In: Johnson, M. E. \& J. Ledesma-Vázquez (eds.). Pliocene carbonates and related facies flanking the Gulf of California, Mexico. Geological Society of America. Special Paper 318. pp. 39-56.

Montresor, M., A. Zingone \& D. Marino. 1993. The calcareous resting cyst of Pentapharsodinium tyrrhenicum comb. nov. (Dinophyceae). J. Phycol. 29(2): 223230.

Montresor, M., D. Janofske \& H.Willem. 1997. The cyst-theca relationship in Calciodinellum operosum emend. (Peridiniales, Dinophyceae) and a new approach for the study of calcareous cysts. J. Phycol. 33(1): 122-131.

Morquecho, L. \& C. H. Lechuga-Devéze. 2003. Dinoflagellate cysts in Recent sediments from Bahía Concepción, Gulf of Mexico. Bot. Mar. 46(2): 132-141.

Morquecho, L. \& C. H. Lechuga-Devéze. 2004. Seasonal occurrence of plankton dinoflagellates and cyst production in relationship to environmental variables in subtropical Bahía Concepción, Gulf of California. Bot. Mar. 47(4): 313-22.

Nehring, S. 1994. Spatial distribution of dinoflagellate resting cysts in recent sediments of Kiel Bight, Germany (Baltic Sea). Ophelia 39(2): 137-58.

Nehring, S. 1995. Dinoflagellate resting cysts as factors in phytoplankton ecology of the North Sea. Helgol. Meeresunters 49(1-4): 375-392. 
Nehring, S. 1997a. Dinoflagellate resting cysts from recent German coastal sediments. Bot. Mar. 40(4): 307-324.

Nehring, S. 1997b. Dinoflagellate resting cysts in recent sediments of the western Baltic as indicators for the occurrence of "non-indigenous" species in the water column. Proceedings of the 13th Baltic Marine Biologists Symposium. Jurmala, Latvia. pp. 79-85.

Okolodkov, Y. B. 1998. A checklist of dinoflagellates recorded from the Russian arctic seas. Sarsia 83(4): 267-292.

Okolodkov, Y. B. 2002. The genus Protoperidinium Bergh in the Mexican Pacific. XII Reunión Nacional de la Sociedad Mexicana de Planctología y V International Meeting of the Mexican Society of Planktology. Xalapa, Veracruz, México. p. 68.

Okolodkov, Y. B. 2005. Protoperidinium Bergh (Dinoflagellata) in the southeastern Mexican Pacific Ocean: part I. Bot. Mar. 48(4): 284-296.

Okolodkov, Y. B. 2008. Protoperidinium Bergh (Dinophyceae) of the National Park Sistema Arrecifal Veracruzano, Gulf of Mexico, with a key for identification. Acta Bot. Mex. 84: 93-149.

Okolodkov, Y. B., M. E. Meave del Castillo \& M. E. Zamudio-Reséndiz. 2003. Diversidad de dinoflagelados planctónicos en el Pacífico Mexicano. Resúmenes de los trabajos presentados en el IV Congreso Mexicano de Ficología. Mérida, Yucatán, México. No. 137. p. 79.

Okolodkov, Y. B. \& I. Gárate-Lizárraga. 2006. An annotated checklist of dinoflagellates (Dinophyceae) from the Mexican Pacific. Acta Bot. Mex. 74: 1-154.

Peña-Manjarrez, J. L., J. Helenes-Escamilla, G. Gaxiola-Castro \& E. Orellana-Cepeda. 2005. Dinoflagellate cysts and bloom events at Todos Santos Bay, Baja California, México, 1999-2000. Cont. Shelf Res. 25: 1375-1393.

Reid, P. C. 1974. Gonyaulacacean dinoflagellate cysts from the British Isles. Nova Hedwigia 25: 579-637.

Rochon, A., A de Vernal, J. L. Turon, J. Matthiessen \& M. J. Head. 1999. Distribution of recent dinoflagellate cysts in surface sediments from the North Atlantic Ocean and adjacent seas in relation to sea-surface parameters. American Association of Stratigraphic Palynologists Contribution Series 35: 1-146.

Sonneman, J. A. \& D. R. A. Hill. 1997. A taxonomic survey of cyst-producing dinoflagellates from recent sediments of Victorian coastal waters, Australia. Bot. Mar. 40(3): 149-77.

Steidinger, K. \& K. Tangen. 1997. Dinoflagellates. In: Tomas, C. R. (ed.). Identifying marine phytoplankton. Acad. Press, Inc. San Diego, California. pp. 387-589.

Taylor, F. J. R. \& G. Gaines. 1989. Dinoflagellate cyst morphology: an analysis based on laboratory observations of encystment. In: Okaichi, T., D. M. Anderson \& T. Nemoto (eds.). Red tides: biology, environmental science, and toxicology. Elsevier. New York. pp. 295-296.

Vargas-Montero, M. \& E. Freer. 2002. Descripción morfológica y ultraestructural de floraciones algales nocivas en el Golfo de Nicoya, Costa Rica y su impacto en la salud. Rev. Costarric. Cienc. Méd. 23(3-4): 115-132.

Wall, D. \& B. Dale. 1966. "Living fossils” in Western Atlantic plankton. Nature 211: 10251026. 
Wall, D. \& B. Dale. 1968. Modern dinoflagellate cysts and evolution of the Peridiniales. Micropaleontology 14(3): 265-304.

Wang, Z., K. Matsuoka, Y. Qi \& J. Chen. 2004a. Dinoflagellate cysts in recent sediments from Chinese coastal waters. Mar. Ecol. 25(4): 289-311.

Wang, Z., Y. Qi, S. Lu, Y. Wang \& K. Matsuoka. 2004b. Seasonal distribution of dinoflagellate resting cysts in surface sediments from Changjiang River Estuary. Phycol. Res. 52(4): 387-395.

Zonneveld, K. A. F. \& B. Dale. 1994. The cyst-motile stage relationships of Protoperidinium monospinum (Paulsen) Zonneveld et Dale comb. nov. and Gonyaulax verior (Dinophyta, Dinophyceae) from the Oslo Fjord (Norway). Phycologia 33(5): 359368. 
